\title{
RNA sequencing using fluorescent-labeled dideoxynucleotides and automated fluorescence detection
}

\author{
Günter J.Bauer \\ Max-Planck Institut für Biophysikalische Chemie, Abteilung Biochemısche Kinetik, Postfach 968, \\ D-3400 Göttingen, FRG
}

Recelved November 9, 1989, Revised and Accepted January 3, 1990

\begin{abstract}
Although dideoxy terminated sequencing of RNA, using reverse transcriptase and oligodeoxynucleotide primers, is now a well established method, the accuracy is limited by sequence amblguities due to unspecific chain termination events. A protocol is described which circumvents these ambiguities by using fluorescence labels tagged to dideoxynucleotides. Only chain terminations caused by dideoxynucleotides were detected while premature terminated CDNA's remain undetectable. In addition, the remaining multiple signals at nucleotide positions can be assigned to sequence heterogeneities within the RNA sequence to be determined.
\end{abstract}

\section{INTRODUCTION}

Direct sequencing of RNA with the chain termination method (1), using reverse transcriptase, specific oligodeoxynucleotides, and dideoxynucleotides $(2,3)$, has become a well established method. Its fast and easy protocol has made it very useful for routine analysis. However, since inaccuracies are inherent to any sequencing protocol, chain termination sequencing has to encounter two major types of strong secondary structure problems which lead to ambigusties in sequence determination, band compressions and premature chain terminations.

Band compressions are caused by secondary structures within the cDNA, evident as discontinuittes in band spacing, sometimes together with rearrangement of fragment order. These artifacts are generated by intermolecular base pairings of the cDNA molecules which affect the Ir electrophoretic mobılity. The more rigid structures even withstand denaturing conditions in sequencing gels containıng urea and separations carried out at high temperatures (4). The secondary structures can be weakened by substituting dITP for dGTP (5) or substituting dGTP or dATP by their $c^{7}$-deaza analogs $(7,6)$. Another approach employs a sequencing gel containing $98 \%$ formaldehyde to increase the denaturing conditions (8).

Premature chain terminations are caused by secondary structures or by modified nucleotides within the RNA template giving additional cDNA molecules with free 3'-hydroxyl groups evident as bands in all lanes. They are interpreted as positions where the dissociation rate of the enzyme template complex is increased $(9,10,11)$. Several investigations have been reported to date to alleviate this problem. These include the prevention of premature chain terminations by the addition of $\mathrm{T} 4$ gene 32 protein to sequencing reactions (12), by treatment of RNA templates with methyl mercury $(13,14)$, and by reverse transcription at elevated temperatures $(8,15)$. Another approach uses tailing of the cDNA molecules with free $3^{\prime}$-hydroxyl groups with a successive chase of increasing deoxynucleotide concentrations using reverse transcriptase $(2,16)$ or terminal deoxynucleotide transferase (17).

Self-replicating RNA molecules, as replicated by $\mathrm{Q} \beta$-replicase $(18,19,20)$ are quite difficult to sequence. One has to deal with an ensemble of closely related RNA's, a subtly structured mutant distribution centered around one or several master sequences (21). Such a distribution of sequences, if stationary, is called a quasispecies $(22,23,24)$. The latter, is characterized by an average sequence, which, in most cases, is homologous to the sequence of the highest populated RNA, i.e., the master sequence. The melting curves of self-replicatıng RNA's show sharp single melting transitions at high temperatures up to $76^{\circ} \mathrm{C}$ in a $50 \%$ formamide solution containing $0.1 \times \mathrm{SSC}$ (see experimental), indicatıng a highly cooperative meltung of secondary and tertiary structures (25). In pure water they would have melting points above $100^{\circ} \mathrm{C}$. Sequence determinations also have been performed by the two dimensional gel electrophoresis method $(26,27,28)$ and enzymatic base specific cleavage $(29,30)$. These methods are either laborious or require multiple analysis for a high degree of accuracy. Another approach uses $\mathrm{Q} \beta$-replicase and $\alpha$-labelled 3 '-deoxynucleotides (31) which are not commercially available and therefore must be synthesized using large amounts of radioactivity. By adopting chain termination sequencing for fast routine determinations of the average sequence of the quasıspecies, one encounters several regions with extensive premature chain terminations caused by their very tight structures. These artifacts can not be removed to a satisfactory extent by the methods mentioned above. Several sequence runs are usually necessary to obtain accurate data, nevertheless some regions remain unreadable.

More recently automated sequencing of nucleic acids has been introduced with fluorescent labels either tagged to a primer $(32,33)$ or to the dideoxynucleotide (6). Sequencing with fluorescent dideoxynucleoside triphosphates (F-ddNTP) has the advantage of detecting only the molecules with F-ddNTP at their $3^{\prime}$ ends, while molecules with free $3^{\prime}$ hydroxyl groups remain undetectable. Therefore, sequencing with F-ddNTP should be ideal for routine analysis of RNA-molecules. 


\section{EXPERIMENTAL}

\section{Materials}

Deoxynucleotides and dideoxynucleotıdes were obtained from Du Pont or Pharmacia, $c^{7}$-deaza-dGTP, $c^{7}$-deaza-dATP, and fluorescent labelled dideoxynucleotıdes (F-ddNTP's) were from Du Pont, glycogen was from Boehringer, and all other chemicals employed were of the highest grade available. Solutions used for RNA analysis were prepared with HPLC-quality water (J.T. Baker) and sterile filtered. Radiochemicals were from Amersham (Braunschweig, FRG). Reverse transcriptase from avian myeloblastosis virus $(16,000$ units $/ \mathrm{ml})$ and terminal deoxynucleotide transferase (TdT) were purchased from Genofit (Heidelberg, FRG). Holo $Q \beta$-replicase $(34,35)$ and poly(A) polymerase (36) were prepared as described. A mixture of $23 \mathrm{~S}$ rRNA and 16S rRNA from Escherichua coli was obtained from Boehringer and was used without further purification. Yeast 5.8S rRNA from Saccharomyces cerevisiae was prepared as described (37). $\mathrm{MDV}_{1}$ (38) was a kınd gift from C. H. Biebricher. EBV was derived during exponential phase cultivation (39) of $\mathrm{MDV}_{\mathrm{I}}$ in the presence of high ethidium bromide concentrations (40). The phasing primers $5^{\prime} \mathrm{OH}-(\mathrm{dT})_{10} \mathrm{dGdG}$ and $5^{\prime} \mathrm{OH}-(\mathrm{dT})_{10} \mathrm{dAdA}$ were purchased from Pharmacia and used without further purificatıon. Universal prımers for 16S rRNA sequencing (15) were synthesized on a Gene Assembler Plus (Pharmacia LKB) The deblocked oligodeoxynucleotides were desalted by gel filtration using a NAP 10 column (Pharmacia), dried in vacuo and dissolved in water. They were used without further purification.

\section{Methods}

Growth and purification of self-replicating molecules. A replicatıon mix containing $500 \mu l 50 \mathrm{mM}$ Tris- $\mathrm{HCl}(\mathrm{pH} 7.5)$, $10 \%$ (vol/vol) glycerol, $100 \mathrm{mM} \mathrm{NaCl}, 10 \mathrm{mM} \mathrm{MgCl}, 500 \mu \mathrm{M}$ NTP each, $15 \mu \mathrm{M}$ ethidium bromide and $0.5 \mu \mathrm{M}$ Holo $\mathrm{Q} \beta$ replicase were inoculated with self-replicatıng RNA-molecules and incubated at $30^{\circ} \mathrm{C}$ for 1 hour. After addition of $20 \mu \mathrm{l} 500$ mM EDTA Na-salt ( $\mathrm{pH} 80$ ), the replicase was denatured by intensive mixing for one minute with $500 \mu$ l chloroform/isoamyl alcohol (24: 1, vol/vol) and the phases separated by short centrifugation. The replicase remains as a turbid suspenston between the two phases. The upper phase was carefully removed, mixed with 1 volume $(250 \mu$ l) $7.5 \mathrm{M}$ ammonium acetate, followed by 3 volumes $(2.25 \mathrm{ml})$ ethanol to precipitate the RNA The precipitate was pelleted by centrifugation for 30 minutes at $12,000 \times \mathrm{g}$, and the resultung supernatant was carefully decanted. The final pellet was resuspended in $1 \mathrm{ml} 70 \%$ ethanol, followed by centrifugation for 10 minutes at $12,000 \times \mathrm{g}$ and dissolved in $50 \mu \mathrm{l}$ water. For separation into single strands, the RNA solution was diluted to $0.1 \mathrm{~g} / \mathrm{l}$ in $50 \%$ formamide containing $0.1 \times \mathrm{SSC}$

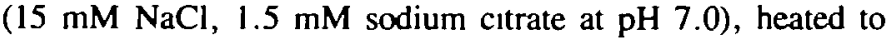
$100^{\circ} \mathrm{C}$ for 2 minutes and immediately chilled to $-70^{\circ} \mathrm{C}$. After rapid thawing the solution was loaded onto a $9 \%$ polyacrylamide gel (30:0.8, acrylamide : bis; dimensions $20 \mathrm{~cm} \times 40 \mathrm{~cm}$ $\times 3 \mathrm{~mm}$ ) containing $50 \mathrm{mM}$ Tris-Borate $(\mathrm{pH} \mathrm{8.3)}$ ), and $1 \mathrm{mM}$ $\mathrm{MgCl}_{2}$. The gel was prerun for 1 hour at 10 watts constant power. The prerun was interupted, 10 minutes before loadıng, to load $100 \mu 190 \%$ formamide containıng $0.1 \%$ xylene cyanol blue. After loading of the sample, electrophoresis was performed at 10 watts constant power until the dye had migrated to the middle of the gel. The RNA bands were located by their UV shadow, cut out and electroeluted (41) into an ion exchange column filled with $100 \mathrm{mg}$ Quiagen (Diagen, Düsseldorf). The
RNA was eluted from the column with $1 \mathrm{ml}$ elution buffer containing $50 \mathrm{mM}$ MOPS-NaOH (pH 7.0), $2 \mathrm{M}$ urea, $1.05 \mathrm{M}$ $\mathrm{NaCl}$, and 15\% (vol/vol) ethanol, followed by precipitation with $1 \mathrm{ml}$ isopropanol, and subsequently pelleted for 1 hour at $32,000 \times \mathrm{g}$. The pellet was washed with $500 \mu \mathrm{l} 70 \%$ ethanol, centrifuged, and finally dissolved in $50 \mu \mathrm{l}$ water.

Polyadenylatıon. Polyadenylation of EBV , single strands and 5.8S rRNA was conducted as described (36). Chloroform denaturing of the poly(A)-polymerase, by mixing with $100 \mu \mathrm{l}$ chloroform/isoamyl alcohol (24:1), was performed as described above and the solution was desalted by gel filtration using a NAP-5 column (Pharmacia LKB) or by ethanol precipitation. Finally the polyadenylated RNA was dissolved in $25 \mu$ l water resulting in a final concentration of $4 \mu \mathrm{M}$.

Lane finding Primers. F-ddNTP's were attached to primers using reverse transcriptase or $\mathrm{TdT}$. Twelve units AMV reverse transcriptase, $0.4 \mathrm{OD}$ poly(rA), 0.75 nmole $(\mathrm{dT})_{10}$, and $1 \mathrm{nmole}$ F-ddTTP in $20 \mu l 50 \mathrm{mM}$ Tris- $\mathrm{HCl}$ (pH 8.3), $40 \mathrm{mM} \mathrm{KCl}, 10 \%$ (wt/vol) glycerol, $6 \mathrm{mM} \mathrm{MgCl} 2$ were incubated for 1 hour at $38^{\circ} \mathrm{C}$ and finally stopped with $80 \mu \mathrm{l} 2.5 \mathrm{mM}$ EDTA Na-salt (pH 8.0). Twenty units $\mathrm{TdT}, 0.75$ nmole oligodeoxynucleotide, and 1 nmole F-ddGTP in TdT-Mg-buffer containing $140 \mathrm{mM} \mathrm{K}$ Cacodylate ( $\mathrm{pH} 72$ ), $30 \mathrm{mM}$ Tris base, $4 \mathrm{mM} \mathrm{MgCl}_{2}$, and 01 $\mathrm{mM}$ DTT were incubated for 3 hours at $38^{\circ} \mathrm{C}$ and finally stopped with $60 \mu \mathrm{l} 2.5 \mathrm{mM}$ EDTA. The solutions were treated with chloroform/isoamyl alcohol $(24: 1)$ and desalted by gel filtration as described above. The appropriate concentration for lane finding was determined by a test run in the Genesis ${ }^{T M} 2000$ automatic fluorescence detector (Du Pont, Bad Homburg).

Reverse Transcription Reactions. 8 pmole polyadenylated RNA (4 $\mu \mathrm{g}$ 23S/16S rRNA) and 75 pmole (25 pmole) primer in $5 \mu \mathrm{l}$ water were annealed by heating to $95^{\circ} \mathrm{C}$ for 3 minutes and chilling immediately on ice.

Reverse transcriptions using F-ddNTP's were performed as followed. In the four reaction scheme $5 \mu \mathrm{l}$ hybridisation solution, $5 \mu \mathrm{l} 5 \times$ AMV-buffer $(250 \mathrm{mM}$ Tris- $\mathrm{HCl}, 50 \%$ (vol/vol) glycerol, $200 \mathrm{mM} \mathrm{KCl}, 36 \mathrm{mM} \mathrm{MgCl}$, and 2.5 units $/ \mu \mathrm{l}$ reverse transcriptase), and $10 \mu \mathrm{l}$ water were combıned. Four $4 \mu \mathrm{l}$ aliquots were mixed with $1 \mu \mathrm{l}$ of dNTP/ddNTP-mixture (AM8: $125 \mu \mathrm{M}$ $\mathrm{c}^{7}$-deaza-dATP, $500 \mu \mathrm{M}$ dCTP, $\mathrm{c}^{7}$-deaza-dGTP, dTTP, and $15.6 \mu \mathrm{M}$ ddATP, or CM20: $125 \mu \mathrm{M}$ dCTP , $500 \mu \mathrm{M} \mathrm{c}^{7}$-deazadATP, $c^{7}$-deaza-dGTP, dTTP, and $6.3 \mu \mathrm{M}$ ddCTP, or GM20: $125 \mu \mathrm{M} \mathrm{c}^{7}$-deaza-dGTP, $500 \mu \mathrm{M} \mathrm{c}^{7}$-deaza-dATP, dCTP, dTTP, and $6.3 \mu \mathrm{M}$ ddGTP, or TM8: $125 \mu \mathrm{M}$ dTTP, $500 \mu \mathrm{M} \mathrm{c}^{7}$-deazadATP, dCTP, $\mathrm{c}^{7}$-deaza-dGTP, and $15.6 \mu \mathrm{M}$ ddTTP.). In the one reaction scheme, $5 \mu$ l hybridisation solution, $5 \mu \mathrm{l} 5 \times \mathrm{AMV}$ buffer, $10 \mu \mathrm{l}$ water and $5 \mu \mathrm{ldNTP} / \mathrm{ddNTP}$ mixture $(250 \mu \mathrm{M}$ dNTP each, $31 \mu \mathrm{M}$ F-ddATP and F-ddTTP, and $12.5 \mu \mathrm{M}$ FddCTP and F-ddGTP.) were combined. Solutions were incubated at $42^{\circ} \mathrm{C}$ for 15 minutes, reactions were stopped by addition of 1 volume $(5$ or $25 \mu \mathrm{l})$ stop buffer $(5 \mathrm{M}$ ammonium acetate, 15 mM EDTA Na-Salt, and $0.2 \mu \mathrm{g} / \mu \mathrm{l}$ glycogen at $\mathrm{pH} \mathrm{6.0)}$ and precipitated by the addition of 3 volumes $(30$ or $150 \mu \mathrm{l})$ ethanol to remove nonıncorporated nucleotides. After an additional wash with $500 \mu \mathrm{l} 70 \%$ ethanol, the pellets were dissolved in $0.6 \mu \mathrm{l}$ $90 \%$ formamide (vol/vol) containing $10 \mathrm{mM}$ EDTA Na-salt (pH 8.0), 3\% ficoll ( $w t / v o l)$ and a fluorescent-labelled 11-mer (15-mer). The sample was then heated to $95^{\circ} \mathrm{C}$ for 2 minutes and $0.5 \mu \mathrm{l}$ were loaded onto a $6 \%(\mathrm{wt} / \mathrm{vol})$ polyacrylamide gel 
(19: 1 acrylamide : bis, $20 \mathrm{~cm}$ by $40 \mathrm{~cm}$ by $0.3 \mathrm{~mm}$ ) containing $8 \mathrm{M}$ urea, $100 \mathrm{mM}$ Tris-Borate (pH 8.3), and $1 \mathrm{mM}$ EDTA Nasalt ( $\mathrm{pH} \mathrm{8.0)}$. The gel was prerun for 1 hour at 20 watts constant power and electrophoresis was performed for several hours at 20 watts of constant power in a Genesis ${ }^{T M} 2000$ sequencer, equipped with an additional alumina plate, mounted onto the glass plate containing the mirror to prevent temperature gradients within the gel. The time courses of the fluorescence signals of each lane were stored. Interpretation of the raw data of one reaction scheme was done with the Base Caller 3.01 software (Du Pont, Bad Homburg). Certain ambiguities, if present, were interpreted by a successive control reading. Interpretation of the raw data from the four reaction scheme was performed manually.

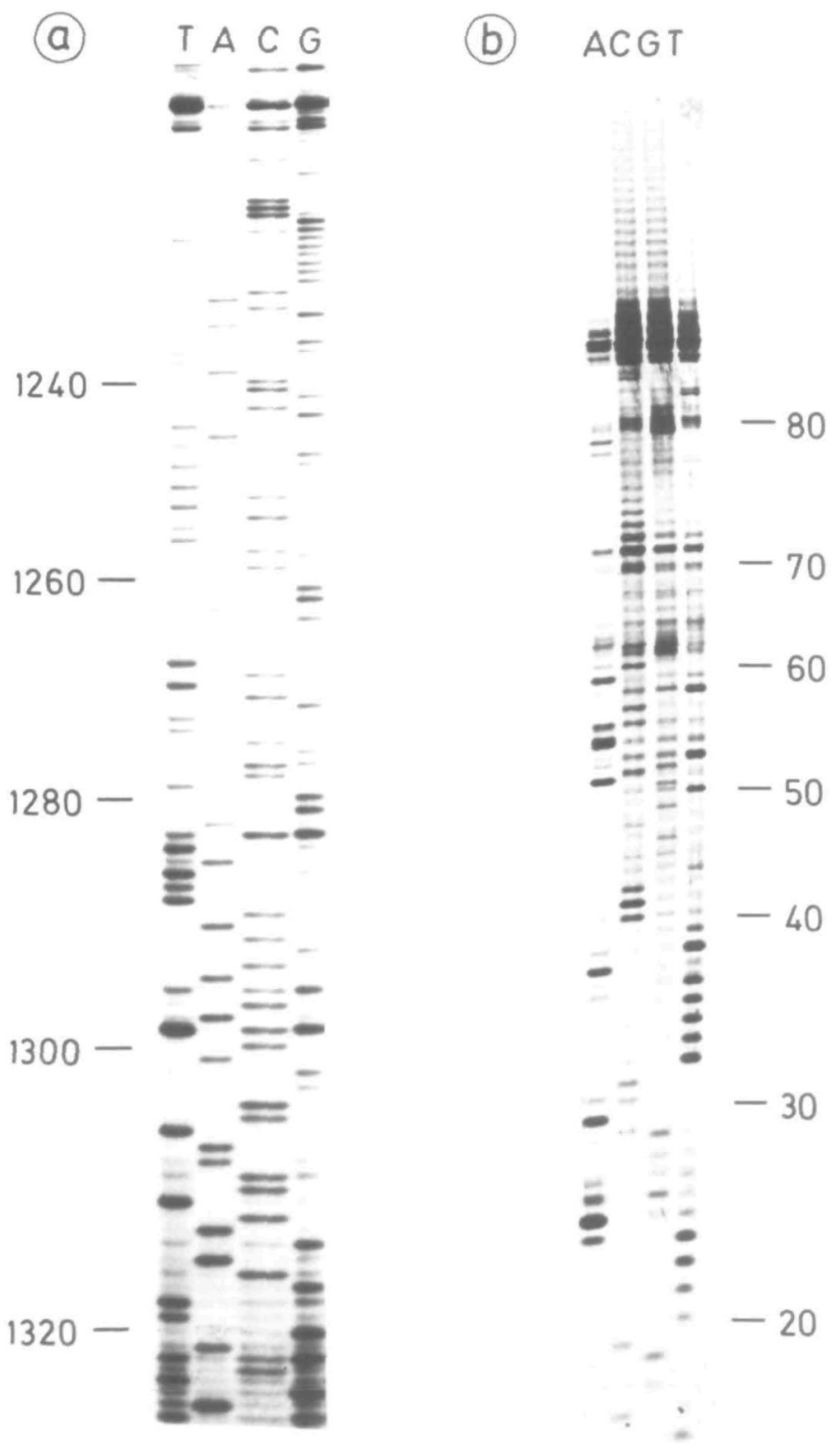

Fig.1 Autoradiograms from RNA sequencings using labelled deoxynucleotides. (a): Sequencing of $16 \mathrm{~S}$ rRNA primed with primer $\mathrm{C}$ (15) extending from position 1392 to 1406 in the $E$. coli $16 S$ rRNA. The numbers indicate the nucleotide position on the RNA. Nucleotide 1300 corresponds to nucleotide 92 read from the sequencing gel. (b): Sequencing of EBV 1 plus strand primed with $5^{\prime}$-(dT) $)_{10} \mathrm{dGdG}$. The sequence reads from 15 to 89 corresponding to bases 13 to 87 on the sequencing gel.
Thirty minutes segments of the raw data were printed, stacked, and aligned. The stacks were put onto a transilluminator to give an overlay of the four time courses from which the fragment order could be read immediately.

Radioactive sequencing using specific labels, was performed as the four reaction scheme above exept using a $5 \times \mathrm{AMV}$ buffer containing either additional $25 \mu \mathrm{Ci}\left[\alpha^{35} \mathrm{~S}\right] \mathrm{dATP}(1000 \mathrm{Ci} / \mathrm{mmol})$ or $10 \mu \mathrm{Ci}\left[\alpha^{32}\right.$ P]dATP (400 Ci/mmol), different dNTP/ddNTP mixtures (AAl: $250 \mu \mathrm{M}$ dCTP, $c^{7}$-deaza-dGTP and dTTP, $.6 \mu \mathrm{M}$ ddATP, or CA5: $250 \mu \mathrm{M} c^{7}$-deaza-dGTP and dTTP, $60 \mu \mathrm{M}$ dCTP, $12 \mu \mathrm{M}$ ddCTP, or GA5: $250 \mu \mathrm{M}$ dCTP and dTTP, $60 \mu \mathrm{M} c^{7}$-deaza-dGTP, $12 \mu \mathrm{M}$ ddGTP, or TA1: $250 \mu \mathrm{M}$ dCTP and $\mathrm{c}^{7}$-deaza-dGTP, $60 \mu \mathrm{M}$ dTTP, $12 \mu \mathrm{M}$ ddTTP.), chasing the reactions by addition of $1 \mu \mathrm{l}(250 \mathrm{mM}$ MOPS-Na (pH 6.4), 1 $\mathrm{mM}$ dNTP each, and 1 unit/ $\mu \mathrm{l}$ TdT) following a second

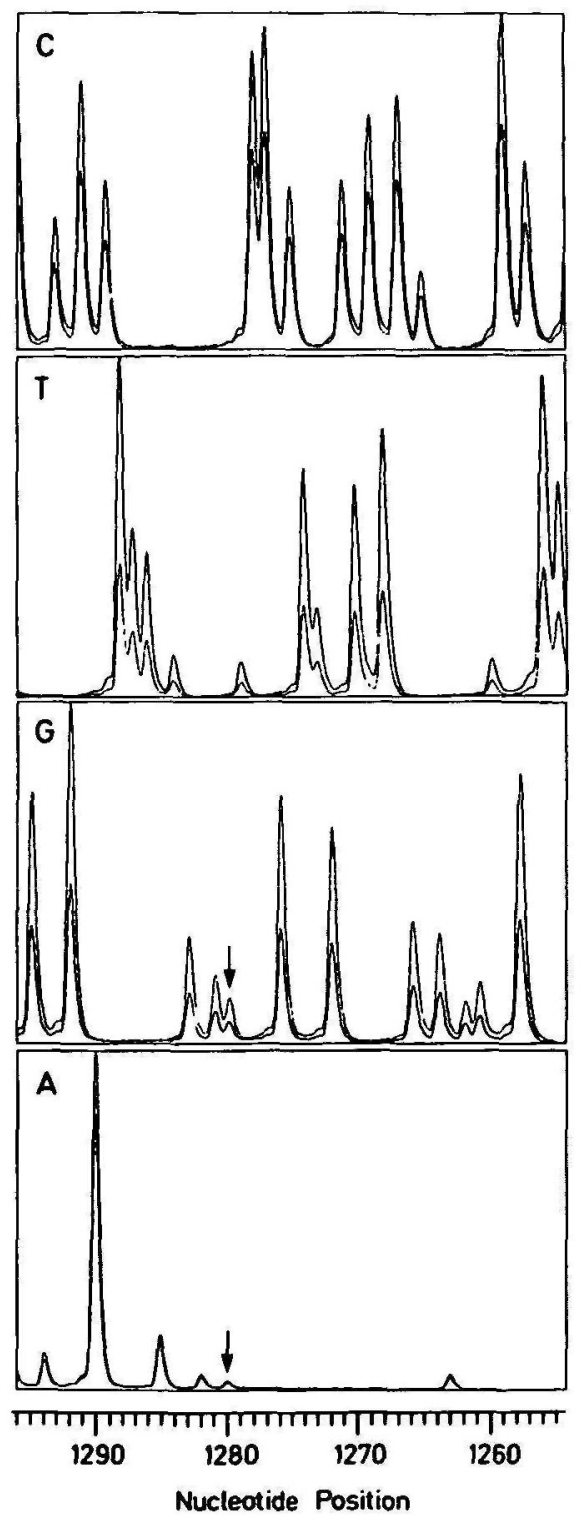

Fig.2 Partial raw data output from a 6\% polyacrylamide gel showing the sequence of $16 \mathrm{~S}$ rRNA primed with primer C (see fig. 1a). The sequence reads from 1276 to 1250 corresponding to the bases 116 to 142 on the gel. Arrows indicate bases which were correspondingly detected at the same time, showing a sequence heterogeneity. 
incubation period at $38^{\circ} \mathrm{C}$ for 30 minutes, and dissolving the pellets in $6 \mu \mathrm{l} 90 \%$ formamide containing $10 \mathrm{mM}$ EDTA Nasalt (pH 8.0), 3\% ficoll, $0.1 \%$ bromophenol blue and $0.1 \%$ xylene cyanol blue. $1.5 \mu$ l aliquots of the samples were heated to $95^{\circ} \mathrm{C}$ for 2 minutes and loaded onto a $8 \%$ (wt/vol) wedge shaped polyacrylamide gel $(19: 1$, acrylamide : bis; dimensions, $60 \mathrm{~cm} \times 20 \mathrm{~cm} \times 0.2-0.4 \mathrm{~mm}$, top to bottom) and the electrophoresis was performed at 30 watts constant power until xylene cyanol blue reached the end of the gel. Coating of the glass plates with $\gamma$-methacryloxypropyltrımethoxysilane or dichlorodimethylsilane, gel drying and autoradiography using Cronex 4 $(20 \times 60 \mathrm{~cm}$ unfolded, Du Pont) as X-ray-film were performed as described (42).

\section{RESULTS}

Two types of RNA molecules were studied. The 16S rRNA from Escherichia coli and 5.8S rRNA from yeast as structural RNA's and the plus strand of the self-replicatıng RNA molecule EBV Sequencing of $16 \mathrm{~S}$ rRNA, with reverse transcriptase, has become a routine method and is applied during the phylogenetic analysis of microorganisms $(15,17)$. For $16 \mathrm{~S}$ rRNA, several sequence heterogeneities due to multiple cistrons are known $(43,44)$. For the 5.8S rRNA of Yeast no heterogeneities have been reported thus far. Fig. 1a, shows the autoradiogram of a sequencing run of 16S rRNA using labelled deoxynucleotides. Several ambiguities can be seen. This pattern does not change significantly when using labelled primers. Usually the template nucleotide will be assigned to the most prominent band leading to an average error incidence of $1 \%$ (15). It is obvious that the background, caused by premature terminations, disables the detection of sequence heterogeneties such as at position 1280 where the weak band in the A-lane is due to a minor species (43). Using labelled dideoxynucleotides, the premature chain termınations become invisible as shown in Fig. 2. The small shoulders preceeding the peaks are caused by unpurified primers. When primers purified by gel electrophoresis were used, one symmetrical peak per nucleotide was obtained. Using the four reaction scheme, approximately 250 bases could be determined routinely without any error by a relatively inexperienced person. Concommittantly occuring sequence heterogeneities are observable as ser 1 for position 1280 of the $16 \mathrm{~S}$ rRNA in fig. 2. Only at that position are two peaks (A and G) simultaneously observed.

The employment of four chemically related, yet distinguishable, fluorescent dideoxynucleotides enables the reduction of four sequencing reactions to one reaction and one lane for separation of the cDNA fragments (6). Conducting the one reaction scheme, 150 bases downstream from the primer could be read with an average error rate of $2 \%$ after proofreading. Sequencing using the other 16S rRNA primers gave identical results (data not shown). In some cases, band compressions of GC regions occured but these did not effect the accurate determination of the nucleotide order. In agreement with the results obtained with $16 S$ rRNA sequencing, the sequence of 5.8S rRNA could be determined completely with the four reaction scheme in one single run without any error or ambiguity. Fig. 3 shows the results of a one reaction scheme sequence protocol. The first nucleotides could not be assigned because of their weak signals. Starting the sequence determination 15 bases downstream from the primer, two errors still remained after proofreading of the automatic raw data interpretation.

Sequencıng of self-replicating RNA-molecules replicated by
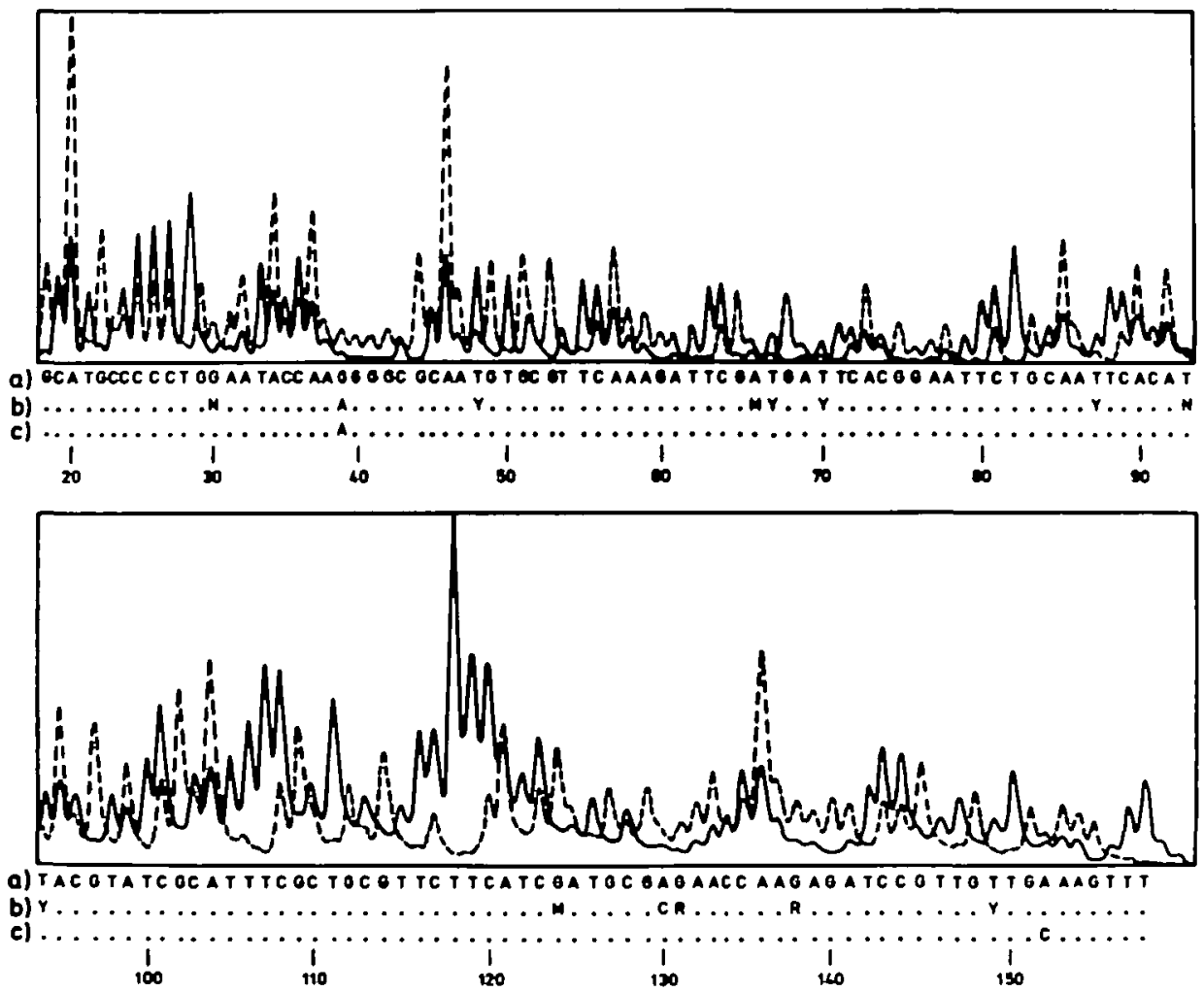

Fig.3 Processed data (base caller 3.01) from a sequencing nun of yeast $58 \mathrm{~S}$ rRNA pnmed with $5^{\prime}$-(dT), 0 dAdA on an 8\% polyacrylamrde gel, (a) indicates une published sequence (45. Rubin), (b) the deviations of the interpretation done by the base caller (Y C or T, M. A or C, R A or G, N. A or G or C or T) and (c) the remaining deviations after manual proofreading 
$\mathrm{Q} \beta$-replicase faces two problems, rigid secondary and tertiary structures and a heterogenous, closely related population due to their quasispecies nature. Both lead to multiple signals at a nucleotide position and cannot certainly be distinguished from another when using labelled deoxynucleotides or primers. Sequence determinations of self-replicating RNA's using the chain termination method with standard protocols and labelled dNTP's or primers gave unsatısfactory results (fig. lb) compared to the sequencing of ribosomal RNA (fig. 1a). Premature chain terminations occur to a very high extent and it is often impossible to assign the template nucleotide to the most prominent band. In the best cases about $70 \%$ of the sequence can be determined. The complete sequences can, however, be determined using labelled dideoxynucleotides together with the four reaction scheme, as shown in fig. 4, for the sequencing of EBV 1 plus strand which could not be resolved when using other labelling methods. Close inspection of the peaks show triplets, as observed by one major peak, preceeded by a very small one and followed by a larger one. It is not known, whether these are caused by heterogenous 3 '-ends or by different secondary structures of one cDNA fragment. For determination of the average quasispecies sequence only the major peaks were taken. The 5 '-end can not be resolved, when using labelled primers or deoxynucleotides, because of the full length cDNA transcripts occuring in every lane. With fluorescent deoxynucleotides, however, the 5 'end can be easily resolved (fig. 3, fig 4.).
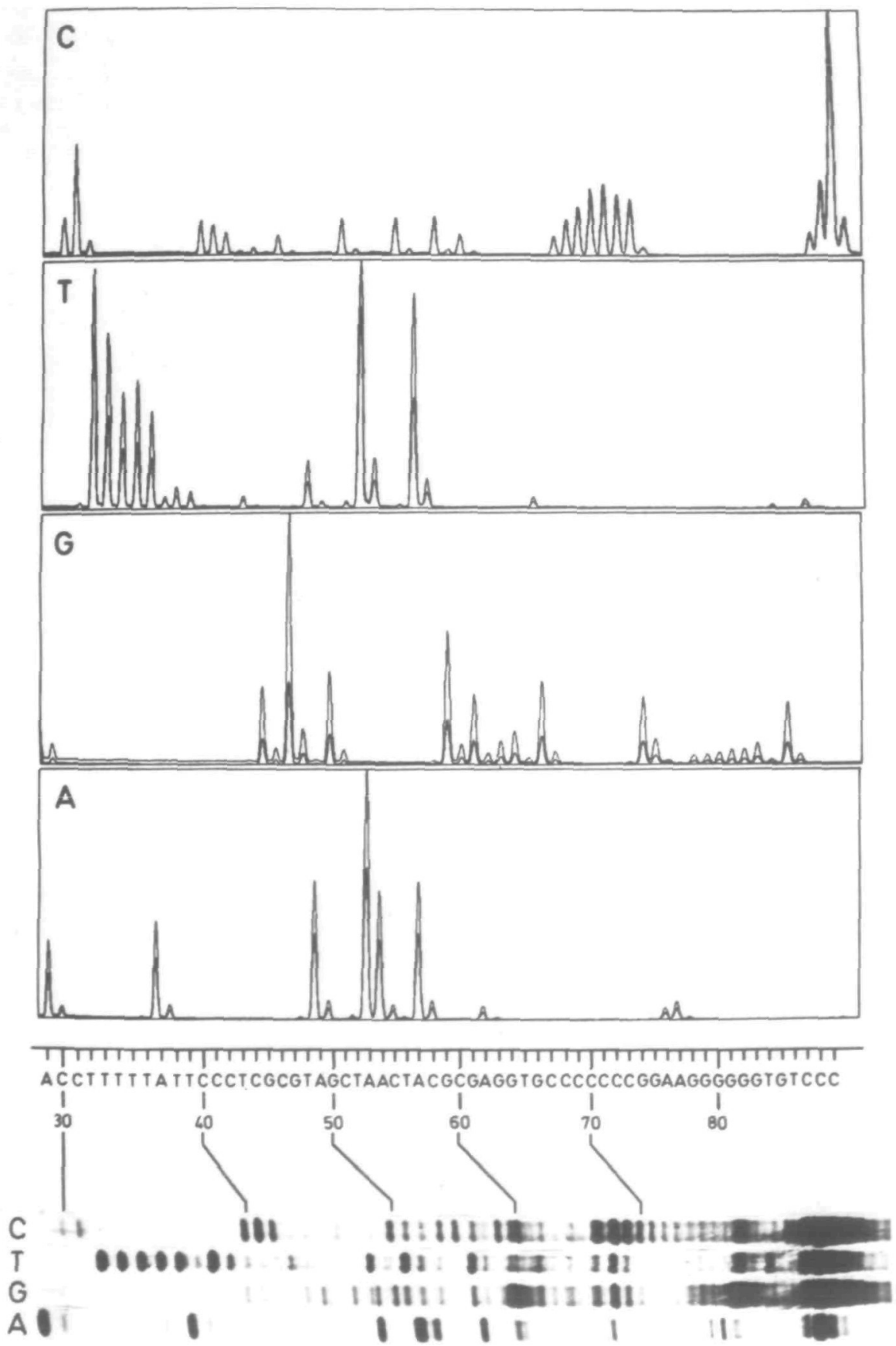

Fig.4 Partual raw data output from a $12 \%$ polyacrylamide gel showing part of the sequence of EBV $\oplus$ from base 29 to 89 (5' end), together with the aligned
autoradiograph from fig $1 \mathrm{~b}$ 


\section{DISCUSSION}

The use of fluorescent labelled dideoxynucleotides enhances the dideoxytermınated sequencing of RNA. Previously observed premature chain terminated cDNA's with free 3 '-OH remain undetectable when using labelled chain terminating molecules, leading to a higher degree of accuracy, comparable to conventional DNA sequencing. Band compressions and rigid structures causing nearly complete termination of reverse transcription $(8,46)$ still may cause uncertainties The use of $c^{7}$-deaza analogs of dATP and dGTP depress band compressions to a very large extent and reverse transcription at elevated temperatures increases traversions through regions with rigid structures (8). Nevertheless, the accuracy of sequence determination in regions leading to these artifacts increases enormously when using fluorescent chain terminators.

The one reaction scheme provides less information per sequencing run than the four reaction scheme but its throughput makes it valuable for routine analysis of easily sequenced molecules such as ribosomal RNA's. The four reaction scheme provides, in addition to the ability to read far more downstream from the promer, a very high accuracy of nucleotide assignment. This makes multiple sequencing of the same regıon, to alleviate the determination of ambiguous positions, unnecessary. Therefore the four reaction scheme is recommended for fast routine sequence determinations of RNA, especially in the case of difficult to sequence RNA molecules, e.g. self-replicatıng RNA occurıng as quasispecies.

Populations of RNA viruses are of quasispecies nature $(47,48,49)$. cDNA clones derived from such populations may not be clones of the master sequence and, therefore, give only limited information about the average sequence. Direct sequencing of these RNA's using F-ddNTP's provides besides the sequence information, insight into the heterogeneity of such populations.

\section{ACKNOWLEDGEMENTS}

The author wishs to thank S. Volker for her technical assistance, $R$. Oberdiek and $M$. Meyer for preparing the figures and photographs, J. Sidhu and J. Yin for careful readıng, and $\mathbf{M}$. Eigen for providing a constantly favourable environment for this research. In addition, the financial assistance offered by the Verband der Chemischen Industrie e.V.-Fonds der Chemischen Industrie-towards the part purchase of the Genesis ${ }^{T M} 2000$ DNA Analysis System is greatfully acknowledged.

\section{REFERENCES}

1 Sanger, F, Nicklen, S. and Coulson, A R (1977) Proc Nat Acad Scı USA, 74, 5463-5467

2 Zimmern, D. and Kaesberg, P. (1977) Proc. Natl. Acad. Sci USA, 75, 4257-4261

3 Hamlyn, P H, Brownlee, G G , Cheng. Ch , Gatt, M J. and Milstein, C (1978) Cell, 15, 1067-1075.

4. Sanger, F and Coulson, A R. (1978) FEBS Lett., 87, 107-110.

5. Mills, D.R and Kramer, F.R (1979) Proc. Natl Acad. Sci. USA, 76, 2232-2235

6. Prober, J M., Traunor, G.L., Dam, R.J., Hobbs, F W., Robertson, Ch W , Zagursky, R.J , Cocuzza, A J., Jensen, M.A and Baumeister, K (1988) Science, 238, 336-341

7 Mizusawa, S, Nishumura, S and Seela, F. (1986) Nucl Acids Res, 15, 1319-1324.

8. Shimomaye, E and Salvato, M. (1989) Gene Anal Techn, 6, 25-28

9. Youvan, D.C , Hearst, J.E (1979) Proc Natl Acad Sci USA, 76, pp $3751-3754$
10 Inoue, $T$ and Cech, T R (1985) Proc Nat Acad ScI USA, 82, 648-652

11 Myers, J C and Splegelmann, S (1978) Proc Natl Acad Sci USA, 75, $5329-5333$

12 O'Farrell, P (1987) Boehringer Mannheım Bıochemıca, 4, 13

13 Barley, J M and Davidson, M. (1976) Anal Biochem, 70, 75-85

14. Buell, G N., Wickens, M.P , Payvar, F and Schumke, R T (1978) J Biol Chem , 253, 2471-2482

15 Lane, D J , Field, K.G, Olsen, G.J and Pace, N R (1989) Meth Enzymol, $164,138-144$.

16 Lane, D J , Pace, B , Olsen, G J, Stahl, D A, Sogin, M L and Pace, N (1985) Proc Nat Acad Sc1 USA, 82, 6955-6959

17. DeBorde, D C , Naeve, C W., Herlocher, M L and Maassab, H F (1986) Anal B1ochem, 157, 275-282

18 Mills, D R, Peterson, R I and Spiegelman, S (1967) Proc Natl Acad Sc1 USA, 58, 217-224

19 Brebncher, C K (1983) In Hecht, M K , Wallace, B and Prance, G T (eds), Evolutıonary Biology Plenum Press, New York, Vol 16 pp 1-52

20 Biebricher, C K and Eigen, M (1988) In Domingo, E, Holland, J J , and Ahlquist, $P$ (eds), RNA Genetics CRC Press, Boca Raton, Vol 1 pp $1-21$

21 Eigen, M (1971) Naturwiss., 58, 465-523

22 Eigen, $M$ and Schuster, P. (1978) The Hypercycle-A principle of natural self-organization Spnnger-Verlag, Heidelberg

23 Eigen, M and Biebricher, C K. (1988) In Domingo, E, Holland, J J , and Ahlquist, P , (eds ), RNA Genetres CRC Press, Boca Raton, Vol 3 pp 211-245

24 Eigen, M, Mccaskıll, J S , Schuster, P (1988) Adv Chem Phys, 75, $149-263$

25 Brebricher, C K , Dieckmann, S and Luce, R (1982) J Mol Biol , 154, $629-648$

26 Muls, D R, Kramer, F R and Spiegelman, S (1973) Science, 180, 916-927

27 Mılls, D R , Kramer, F R , Dobkın, C , Nıshuhara, T and Spıegelman, S (1975) Proc Natl Acad Sc1 USA, 72, 4251-4256

28 Schaffner, W , Ruegg, K J and Welssmann, C (1977) J Mol Biol , 117, $877-907$

29 Donis-Keller, H , Maxam, A M and Guber, W (1977) Nucleic Acids Res , 4, 2527-2538.

30 Munıshkın, A V , Voronin, L A and Chetverin, A B (1988) Nature, 333, $473-475$

31 Kramer, F R and Mills, D R (1978) Proc Natl Acad Scı USA, 75, $5334-5338$

32 Ansorge, W, Sproat, B, Stegemann, J, Schwager, Ch. and Zenke, M (1986) J Biochem Biophys Meth, 11, 315-323

33 Smth, L.M , Sanders, J Z , Kaiser, R J , Hughes, P, Dodd, C, Connell, C R. Heiner, C, Kent, S B H. and Hood, L E (1986) Nature, 321, $674-679$

34 Kamen, R (1972) BBA, 262, 88- 100

35 Bauer, G J , McCaskill, J , Otten, H (1989) Proc Natl Acad Scı USA, 86, $7937-7941$

36 Sippel, A E (1973) Eur J Biochem, 37, 31-40

37 Rubin, G M (1975) In Prescot, D M , (eds ), Methods in Cell Bıology Academic Press, New York, Vol 12 pp 45-64

38 Kacian, D L , Mills, D R , Kramer, F R and Spregelman, S (1972) Proc Natl Acad. Sc1 USA, 69, 3038-3042

39. Brebricher, C K , Eigen, M and Gardıner, W C Jr. (1983) Biochemistry, $22,2544-2558$

40 Bauer, G J (1990) in preparation

41 Bauer, G.J , Lindemann, B (1989) submitted to Anal Biochem

42 Ansorge, W and De Macyer, L (1980) J Chromat, 202, 45-53

43 Cabon, P, Ehresmann, C, Ehresmann, B and Ebel J -P (1979) Eur J. Biochem, 100,399-410

44 Brosius, J , Palmer, M L, Kennedy. P.J. and Noller, H F (1978) Proc Natl Acad Scl USA, 75, 4801-4805

45 Rubin,G M. (1973) J Biol. Chem , 248, 3860-3875

46 Tuerk, C, Gauss, P, Thermes, C, Groebe, D R, Gayle, M , Gull, N, Stormo, G, D'Aubenton-Carafa, Y , Uhlenbeck, O C , Tinoco,Jr., I , Brody, E. and Gold, L. (1988) Proc Natl Acad Sci USA, 85, 1364-1368.

47 Domingo, E , Sabo, D , Tanıguchi, T \& Weissmann, Ch (1978) Cell, 13, $735-744$

48 Domingo,E , Martuna Salas, E , Sobnino, F., de la Torre, J C , Portela, A , Ortun, J. Lopez-Galındez, C , Perez-Brena, P, Villanueva, N, Najera, R, VandePol, S., Steınhauer, S , DePolo, N and Holland, J. (1986) Gene, 40, $1-6$.

49 Meyertans, A, Cheynuer, R, Albert, J, Seth, M, Kwok, S, Snınsky, J., Morfeld-Månson, L, Asృz, B and Waın-Hobson, S. (1989) Cell 58, $901-910$ 